\title{
Improved Switched-Inductor Quasi-Switched-Boost Inverter with Low Input Current Ripple
}

\author{
Andrii Chub (Junior Researcher, Tallinn University of Technology), Liisa Liivik (Researcher, Tallinn University of \\ Technology), Janis Zakis (Senior Researcher, Riga Technical University), Dmitri Vinnikov (Senior Researcher, \\ Riga Technical University)
}

\begin{abstract}
The quasi-switched-boost inverter is an alternative to the quasi- $Z$-source inverter. Its passive component number is two times smaller but it contains two additional semiconductor components. Earlier the switched-inductor cell was applied in this topology to enhance de voltage gain at the cost of high input current ripple. This paper proposes a novel switched-inductor quasi-switched-boost inverter topology with low input current ripple and enhanced dc voltage gain. It is based on a modified switched-inductor cell where the input source is connected in series with an inductor. Operation principle is described through separation of the switching period into three intervals. Equivalent circuits and circuit equations are shown for each interval. Simulation study corroborates theoretical predictions.
\end{abstract}

Keywords - dc-ac converter, inverter, impedance-source inverter, switched-boost inverter, switched-inductor.

\section{INTRODUCTION}

Impedance-source (IS) converters are an emerging technology of single-stage buck-boost electric energy conversion for applications with wide input voltage variations [1]. This field of research was initiated in 2003 after Z-source inverter (ZSI) was proposed in [2]. The IS technology was applied to dc-dc and ac-ac converters, inverters, circuit breakers to overcome limitations of conventional solutions $[1],[3],[4]$. Hence, application range of the IS technology is wide, while most of the studies show their superior performance in renewable and alternative energy, and motor applications. The quasi-Z-source inverter (qZSI) was derived from ZSI by position rearrangement of the input source to achieve continuous input current and lower voltage stress, while saving all advantages of the ZSI [5],[6]. Since then the ZSI and the qZSI are usually considered as reference topologies of IS inverter. They provide buck-boost operation by controlling the modulation index in the buck mode and the shoot-through state duration in the boost mode. However, the relatively high number of passive components can cause a small efficiency drop as compared to conventional solutions.

The switched-boost inverter (SBI) was proposed in [7] as a simpler alternative to the ZSI that contains only a single capacitor and a single inductor. This is half as many passive components as in the ZSI. The SBI features discontinuous input current and lower dc voltage gain than that of the ZSI/qZSI. Moreover, it requires an additional diode and an auxiliary switch. The quasi-switched-boost inverter (qSBI) shown in Fig. 1 is an improved derivative of the SBI and thus contains the same number of components. It was first proposed in [8] and recently extended to a family of the qSBI

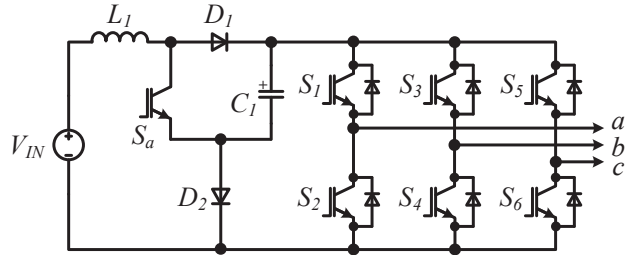

Fig. 1. Quasi-switched-boost inverter (qSBI) topology [8], [9].

topologies in [9]. As distinct from the SBI, the qSBI provides continuous input current and the same dc voltage gain as the qZSI. In practice the qSBI can outperform the qZSI by voltage step-up due to a lower number of passive components, which results in lower parasitic losses within them [10].

In emerging energy applications with wide voltage variations, like solar photovoltaic and wind energy, nonisolated inverters with high dc voltage gain are required for grid integration. They allow utilization of low voltage/energy levels and thus maximize energy yield in unfavorable climatic conditions. The qSBI seems an attractive topology that could overcome limitations of the qZSI, while its dc voltage gain is rather moderate and thus has to be improved.

Dc voltage gain can be improved using one of three major techniques, which were applied to IS inverters recently. First, IS network can be cascaded to enhance dc voltage gain, like in extended boost cascaded qZSI [11]. However, this method requires additional passive components. Second, coupled inductors can be used to derive a new IS network with higher dc voltage gain [12]-[16]. However, most of them suffer from duty cycle loss caused by leakage inductance of a coupled inductor [17]. Third, switched-inductor and switched-capacitor cells proposed in [18], as well as other voltage lift cells derived from them [15], [19], can be applied to most of the IS networks. Hence, it has been applied to the ZSI [20]-[23], the qZSI [24]-[27] and other inverters. The switched-inductor cell (SL) is used most extensively for dc voltage gain enhancement.

The SL cell was applied to SBI in [28] to enhance its dc voltage gain. The qSBI has also benefited from the utilization of the SL. The switched-inductor qSBI (SL-qSBI) presented in [29] has improved the dc voltage gain characteristic, while the input current ripple is much higher than that in the qSBI. The input current ripple of the SL-qSBI (Fig. $2 a$ ) is equal to the average current of the SL inductors $\mathrm{L}_{1}, \mathrm{~L}_{2}$ (Fig. $2 b$ ).

This paper presents an improved SL-qSBI with low input current ripple (cSL-qSBI). It is derived from the SL-qSBI by moving of the input source to connect it in series with one of 


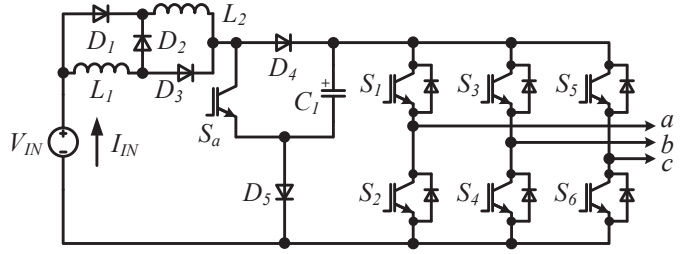

(a)

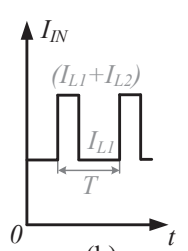

(b)
Fig. 2. The SL-qSBI topology [29] (a) and sketch of its input current (b).

inductors of the SL. A similar approach was used in [22], [26] to improve switched-inductor based ZSI and qZSI. It results in considerable reduction of the input current ripple. Moreover, this paper describes differences in the current ripple of the SL inductors, which was not shown in [22] and [26]. Different voltages applied to these inductors during shoot-through state result in different current ripple and dividing of the conventional active state into two different sub-intervals.

\section{DERIVATION AND OPERATION PRINCIPLE OF IMPROVED SWITCHED-INDUCTOR QSBI}

\section{A. Derivation of the $c S L-q S B I$}

A sketch of input current ripple of the SL-qSBI is shown in Fig. $2 b$. The current ripple is considerably higher than that of the qSBI, while the current ripple of the inductors of SL is much lower. Hence, the input source can be connected in series with one of them to decrease the input current ripple, as shown in Fig. 3. The cSL-qSBI proposed contains the same amount of components as the SL-qSBI: five diodes $D_{1} \ldots D_{5}$, a single auxiliary switch $S_{a}$, a single capacitor $C_{l}$, two inductors $L_{1}$ and $L_{2}$, and the three-phase voltage-source inverter $S_{1} \ldots S_{6}$.

\section{B. Operation Principle of the cSL-qSBI}

Operation principle of the cSL-qSBI can be described using a simplified circuit shown in Fig. 4. The resistance $R_{l d}$ is representing a load of the inverters. It is assumed to be constant since the dynamics of the inverter is relatively slow and there is an insignificant change of the load current during a single switching period $T$. The switch $S_{p n}$ is used to imitate

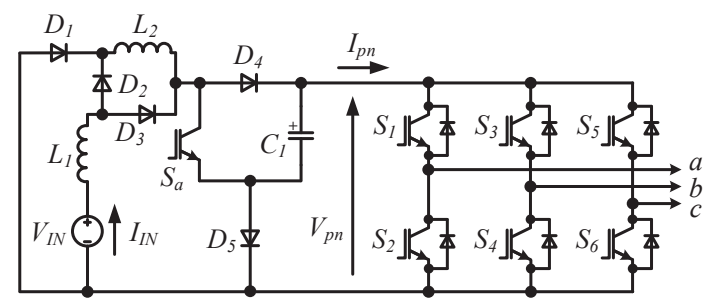

Fig. 3. Proposed cSL-qSBI topology that features low input current ripple.

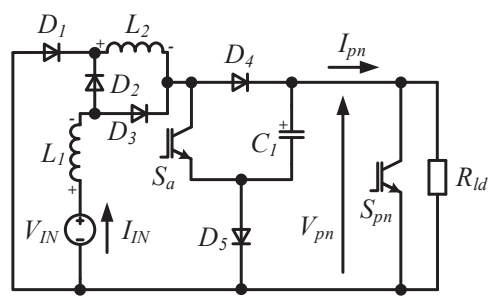

Fig. 4. Simplified circuit of the cSL-qSBI. the shoot-through state. It is controlled synchronously with the auxiliary switch $S_{a}$ - they both are turned on during the shootthrough state. For simplicity it is assumed that $L_{1}=L_{2}=L$.

Idealized voltage and current waveforms that describe the operation principle of the lossless converter are shown in Fig. 5. It is evident that currents of the SL inductors differ as they operate with different voltages. Both switches are controlled using the same switching sequence. Since the SL inductors operate asymmetrically, certain time is required to equalize this current at the beginning of the active state.

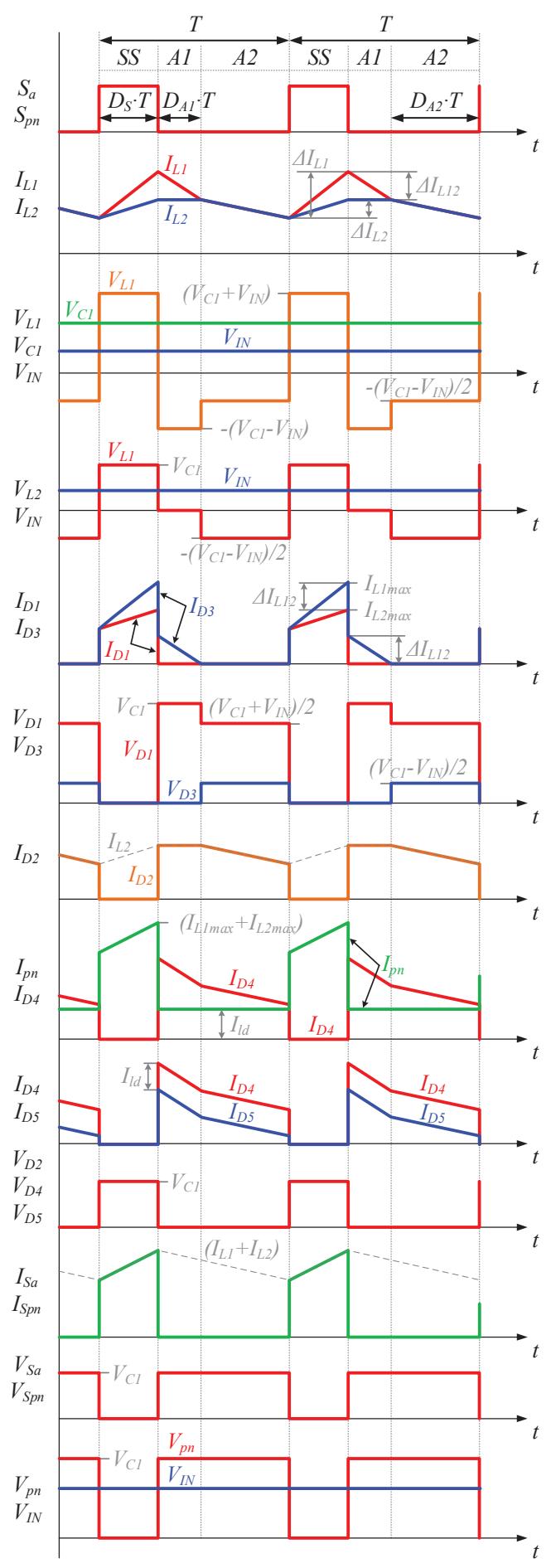

Fig. 5. Idealized current and voltage waveforms of the cSL-qSBI. 
Consequently, the cSL-qSBI features two different active states. Hence, the switching period can be divided into three time intervals.

1) $\boldsymbol{S S}$ - the converter is in the shoot-through state. Equivalent circuit for this state is shown in Fig. $6 a$. Both switches are turned on. The output of the active IS network is short-circuited with the switch $S_{p n}$. The input source $V_{I N}$ and the capacitor $C_{1}$ are charging inductors $L_{1}, L_{2}$, and thus their currents are rising. Meanwhile, their rates of rise are different due to reduced voltage applied to the inductor $L_{2}$, as compared to the conventional SL-qSBI [29]. Hence, the current $I_{L I}$ reaches higher value than the current $I_{L 2}$, considering that $L_{1}=L_{2}$. The capacitor $C_{1}$ is discharging with current $\left(I_{L 1}+I_{L 2}\right)$ during this interval. The SL inductors accumulate energy to be released during the active state. The duration of this interval is $D_{S} \cdot T$, where $D_{S}$ is the shoot-through duty cycle. The following equations are describing the shoot-through state:

$$
\begin{gathered}
V_{L 1}=L \frac{d I_{L 1}}{d t}=V_{C 1}+V_{I N}, \\
V_{L 2}=L \frac{d I_{L 2}}{d t}=V_{C 1}, \\
V_{p n}=V_{S a}=0, \\
I_{S a}=I_{p n}=-I_{C 1}=I_{L 1}+I_{L 2}, \\
V_{D 1}=V_{D 3}=0, \\
V_{D 2}=V_{D 4}=V_{D 5}=V_{C 1}, \\
I_{D 1}=I_{L 2}, \\
I_{D 3}=I_{L 1}, \\
I_{D 2}=I_{D 4}=I_{D 5}=0, \\
\Delta I_{L 1}=\frac{V_{C 1}+V_{I N}}{L} \cdot D_{S} \cdot T, \\
\Delta I_{L 2}=\frac{V_{C 1}}{L} \cdot D_{S} \cdot T, \\
\Delta I_{L 12}=\frac{V_{I N}}{L} \cdot D_{S} \cdot T .
\end{gathered}
$$

2) $\boldsymbol{A 1}$ - the converter is in the first active state. During this time interval the SL inductors release energy to the load. The load is simulated with current $I_{l d}=V_{C l} / R_{l d}$. An equivalent circuit for this state is shown in Fig. $6 b$. A process of current equalizing of the SL inductors defines this interval, which ends when currents of the SL inductors are equal. This type of active state is obvious in the modified SL used here and in [22], [26]. However, this behavior has not been reported anywhere before. The diode $D_{3}$ is conducting the surplus current $\left(I_{L 1}-I_{L 2}\right)$. Hence, zero voltage is applied to the inductor $L_{2}$ and thus its current $I_{L 2}$ is constant, while the current $I_{L 1}$ is decreasing. The SL supplies the load current and charges the capacitor $C_{1}$ simultaneously. The duration of this interval is $D_{A I} \cdot T$. The following equations describe the first active state:

$$
\begin{gathered}
V_{L 1}=L \frac{d I_{L 1}}{d t}=-\left(V_{C 1}-V_{I N}\right), \\
V_{L 2}=L \frac{d I_{L 2}}{d t}=0
\end{gathered}
$$

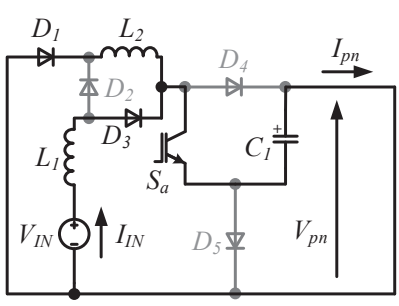

(a)

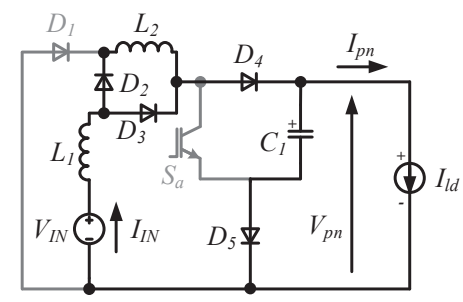

(b)

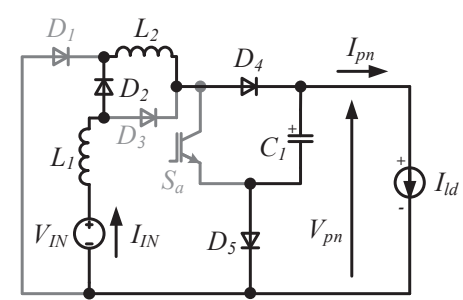

(c)

Fig. 6. Equivalent circuits of the proposed cSL-qSBI topology for: (a) shootthrough state $S S$, (b) first active state $A 1$, and (c) second active state $A 2$.

$$
\begin{gathered}
V_{p n}=V_{S a}=V_{C 1}, \\
I_{S a}=0, \\
I_{p n}=I_{l d}=\frac{V_{C 1}}{R_{l d}}, \\
V_{D 1}=V_{C 1}, \\
V_{D 2}=V_{D 3}=V_{D 4}=V_{D 5}=0, \\
I_{D 1}=0, \\
I_{D 2}=I_{L 2}, \\
I_{D 3}=I_{L 1}-I_{L 2}, \\
I_{D 4}=I_{L 1}, \\
I_{D 5}=I_{C 1}=I_{L 1}-I_{l d} .
\end{gathered}
$$

3) $\mathbf{A 2}$ - the converter is in the second, conventional, active state. During that time interval the SL inductors continue releasing energy to the load. Equivalent circuit for this state is shown in Fig. $6 c$. This interval ends at the end of the period, i. e. $D_{A 2}=\left(1-D_{S}-D_{A 1}\right)$. The diode $D_{3}$ stops conducting because the currents of the SL inductors are equal: $I_{L 1}=I_{L 2}$. These currents are decreasing with the same slope. The SL continues supplying the load current and charging the capacitor $C_{l}$ simultaneously. The following equations are describing the second active state:

$$
\begin{gathered}
V_{L 1}=V_{L 2}=L \frac{d I_{L 1}}{d t}=L \frac{d I_{L 2}}{d t}=-\frac{\left(V_{C 1}-V_{I N}\right)}{2}, \\
V_{p n}=V_{S a}=V_{C 1}, \\
I_{S a}=0,
\end{gathered}
$$




$$
\begin{gathered}
I_{p n}=I_{l d}=\frac{V_{C 1}}{R_{l d}}, \\
I_{L 1}=I_{L 2}, \\
V_{D 1}=\frac{V_{C 1}+V_{I N}}{2}, \\
V_{D 3}=\frac{V_{C 1}-V_{I N}}{2}, \\
V_{D 2}=V_{D 4}=V_{D 5}=0, \\
I_{D 1}=I_{D 3}=0, \\
I_{D 2}=I_{D 4}=I_{L 1}=I_{L 2}, \\
I_{D 5}=I_{C 1}=I_{L 1}-I_{l d} .
\end{gathered}
$$

The operation principle described before features two types of active state. The rate of fall of the current $I_{L I}$ differs by a factor of two for these two active states. Also, the inductor $L_{2}$ can be rated for lower saturation current as compared to the inductor $L_{l}$. This section described the operation principle of the converter in continuous conduction mode (CCM) when the current of the diode $D_{5}$ does not drop to zero.

\section{Steady State ANAlysis AND Discussions}

\section{A. Steady State Analysis}

It is evident from the previous section that current $I_{L 1}$ falls by $\Delta I_{L 12}$ during the first active state:

$$
L \frac{\Delta I_{L 12}}{D_{A 1} \cdot T}=V_{C 1}-V_{I N} .
$$

Substituting (12) into (36), a ratio between $D_{A l}$ and $D_{S}$ can be found:

$$
D_{A 1}=D_{S} \cdot \frac{V_{I N}}{V_{C 1}-V_{I N}} .
$$

In (37) and before, it can be assumed that $V_{C l} \geq V_{I N}$. To find the ratio between $D_{A 2}$ and $D_{S}$, first, the voltage-second balance has to be applied to the inductor $L_{2}$ :

$$
D_{S} \cdot V_{C 1}=D_{A 2} \cdot \frac{V_{C 1}-V_{I N}}{2} .
$$

Then the required duty cycle ratio from (38) is as follows:

$$
D_{A 2}=D_{S} \cdot \frac{2 \cdot V_{C 1}}{V_{C 1}-V_{I N}} \text {. }
$$

From (37) and (39) it follows that

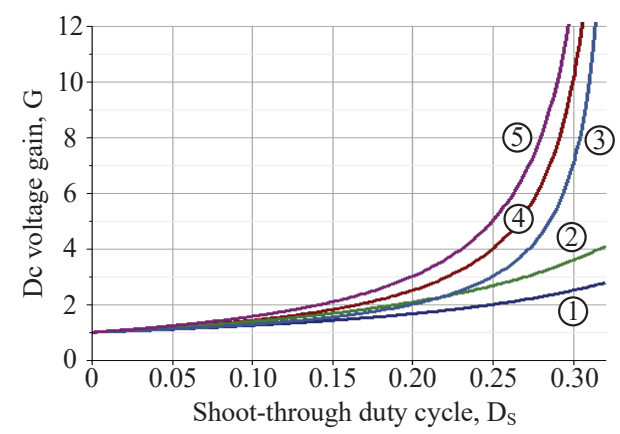

$$
1-D_{S}=D_{A 1}+D_{A 2}=D_{S} \cdot\left(\frac{V_{I N}+2 \cdot V_{C 1}}{V_{C 1}-V_{I N}}\right) \text {. }
$$

The dc voltage gain $G$ of the cSL-qSBI follows from (40):

$$
G=\frac{V_{C 1}}{V_{I N}}=\frac{1}{1-3 \cdot D_{S}} .
$$

\section{B. Comparison with Counterparts}

Comparison of the dc voltage gains of the cSL-qSBI proposed with other IS inverters with extended boost features is shown in Fig. 7. The following counterparts were taken for this comparison: the conventional ZSI and qZSI [1],[5], the diode assisted qZSI (DA-qZSI) [30], the switched-inductor SBI [28], the capacitor assisted qZSI (CA-qZSI) [11], the continuous input current switched-inductor quasi-Z-source inverter (cSL-qZSI) [26], the switched-inductor ZSI (SL-ZSI) [23], the ripple input current switched-inductor quasi-Z-source inverter (rSL-qZSI) [26], and the SL-qSBI [29].

All IS inverters used in the comparison were divided into five groups by the dc voltage gain. The cSL-qSBI proposed belongs to group 4 by the dc voltage gain. It means that it features up to $25 \%$ lower dc voltage gain than that of group 5 and up to $30 \%$ higher than that of group 3 .

It is evident from Fig. 7 that group 5 has the best voltage step-up performance, while all IS inverters in this group have either discontinuous current (SL-ZSI), which is not appropriate for most of emerging applications, or continuous input current with high ripple due to two-step modulation of the input current by the SL (rSL-qZSI and SL-qSBI).

All inverters in group 4 provide continuous input current with low ripple. However, the CA-qZSI and cSL-qZSI have high number of components and thus cannot provide high efficiency or power density. Hence, the cSL-qSBI proposed features both low input current ripple and low number of components. These properties make the cSL-qSBI advantageous over its counterparts for modern power electronics applications, like renewable end alternative energy, battery applications, etc. It can provide high efficiency and power density at low realization cost.

\section{Continuous and Discontinuous Conduction Modes}

The operation principle presented above deals with CCM of the cSL-qSBI when the current of the diode $D_{5}$ does not drop to zero during the second active state. Otherwise, the inverter will operate in the discontinuous conduction mode (DCM)
(1) Conventional ZSI or qZSI [1]: $G=\frac{1}{1-2 \cdot D_{S}}$
(2) DA-qZSI [30]: $G=\frac{1}{2 \cdot D_{S}^{2}-3 \cdot D_{S}+1}$
(3) SL-SBI [28]: $G=\frac{1-D_{S}}{1-3 \cdot D_{S}}$
(4) CA-qZSI [11], cSL-qZSI [26], cSL-qSBI: $G=\frac{1}{1-3 \cdot D_{S}}$
(5) SL-ZSI [23], rSL-qZSI [26], SL-qSBI [29]: $G=\frac{1+D_{S}}{1-3 \cdot D_{S}}$

Fig. 7. Comparison of de voltage gain of IS inverters with extended boost features. 
with excessive output voltage (voltage over-boost). This mode is possible when an IS inverter operates with small inductance in an IS network or supplies a load with low power factor [31]. Undesirable voltage stress of the inverter components can be avoided if an additional switch is connected in parallel with the diode $D_{5}$, as shown in Fig. 8. The switch $S_{b}$ can be turned on during the second active state to enable reverse conduction in that branch and thus avoid DCM.

\section{Simulation Results}

Simulation study of the cSL-qSBI was performed to verify theoretical predictions. Simulation model was implemented in PSIM 9 according to the equivalent circuit shown in Fig. 4. The parameters used for the simulation are shown in Table I. Simulation waveforms are shown in Fig. 9. The idealized $V_{C 1}$ voltage was expected at the level of $364 \mathrm{~V}$, while simulation shows $355 \mathrm{~V}$ due to losses in semiconductor components. It also shows the corner point of the current $I_{L l}$, when its rate of falling changes by factor of two at the instant between states $A 1$ and $A 2$. The converter provides the de voltage gain of 1.775 with the shoot-through duty cycle equal to 0.15 .

The simulation results presented are in good agreement with the analysis presented in two previous sections. Losses in semiconductor components influence voltage step-up performance slightly. Hence, the cSL-qSBI is a promising solution due its simplicity and consequently high efficiency.

\section{V.CONCLUSIONS}

This paper proposes a novel improved switched-inductor quasi-switched-boost inverter that features continuous input current with low current ripple. This topology is advantageous over other impedance-source inverters with extended boost features implemented through cascading of components. It has simple structure and high dc voltage gain. The inverter proposed can provide high efficiency and power density. Moreover, it can be easily modified to avoid undesirable DCM operation by adding one more auxiliary switch. The simulation study performed considering losses in semiconductors corroborates theoretical predictions.

Further research could be directed towards modulation techniques and experimental verification of the inverter proposed. Also, operation with small inductance value and low power factor has to be analyzed.

TABLE I

PARAMETERS USED IN SIMULATION MODEL

\begin{tabular}{|c|c|}
\hline Parameter & Value \\
\hline Switching frequency & $25 \mathrm{kHz}$ \\
\hline$L_{1}, L_{2}$ & $500 \mu \mathrm{H}$ \\
\hline$C_{l}$ & $100 \mu \mathrm{F}$ \\
\hline$V_{I N}$ & $200 \mathrm{~V}$ \\
\hline$R_{l d}$ & $50 \Omega$ \\
\hline Forward voltage drop of the diodes & $1.5 \mathrm{~V}$ \\
\hline Saturation voltage of the switches & $2 \mathrm{~V}$ \\
\hline Shoot-through duty cycle, $D_{S}$ & 0.15 \\
\hline Input power & $2.25 \mathrm{~kW}$ \\
\hline
\end{tabular}

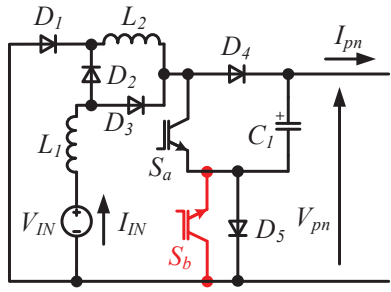

Fig. 8. Modified cSL-qSBI for operation with low inductance or low power factor.

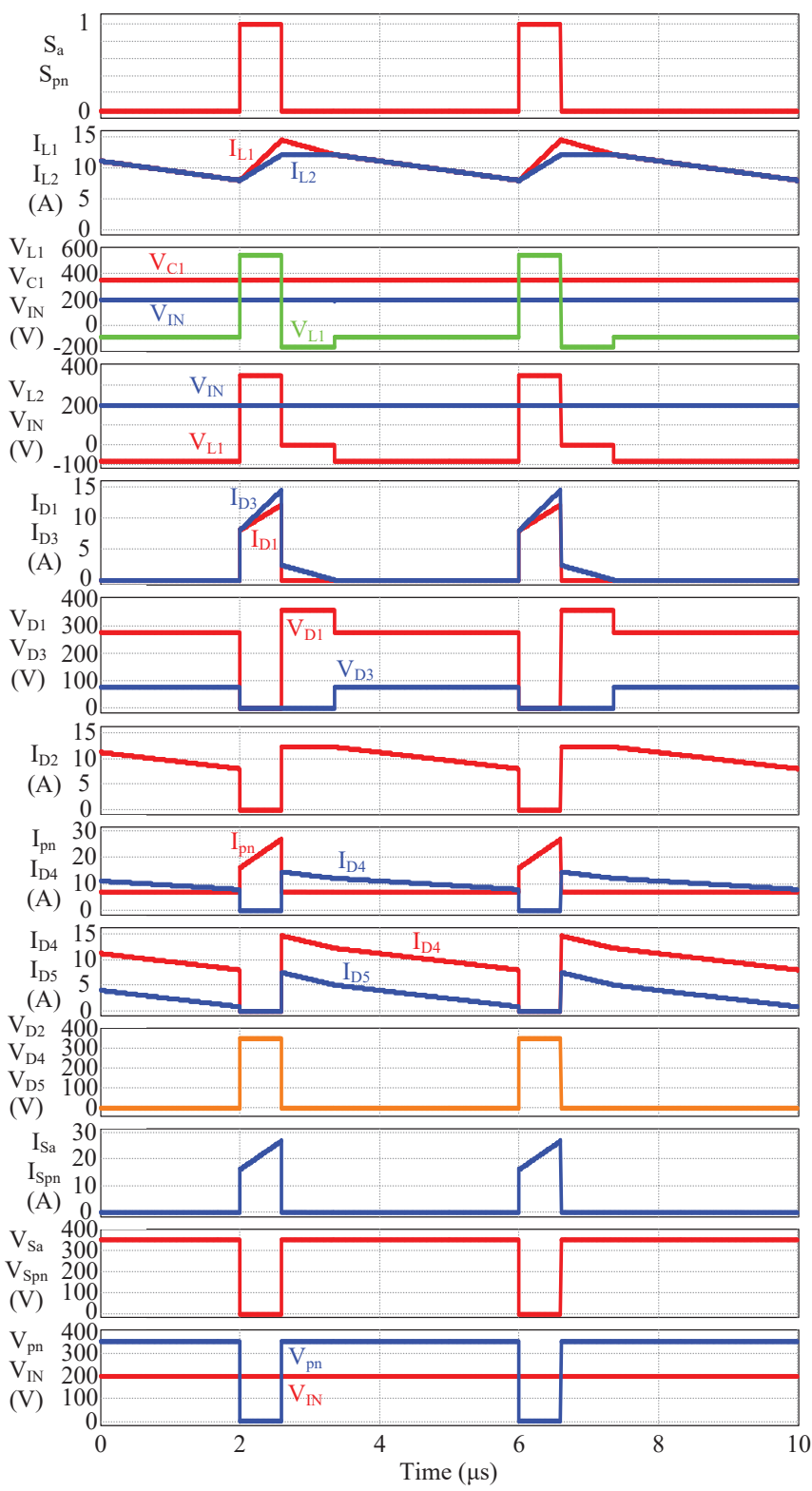

Fig. 9. Simulation results of the cSL-qSBI.

\section{ACKNOWLEDGEMENTS}

This research work was financed by Estonian Ministry of Education and Research (project SF0140016s11) and Latvian Council of Science (Grant 416/2012 and Grant 673/2014). 


\section{REFERENCES}

[1] Siwakoti, Y.P.; Peng, F.Z.; Blaabjerg, F.; Loh, P.C.; and Town, G.E., "Impedance-Source Networks for Electric Power Conversion Part I: A Topological Review," IEEE Trans. on Power Electron., vol.30, no.2, pp.699-716, Feb. 2015.

[2] Peng, F.Z., "Z-source inverter," IEEE Trans. on Ind. Appl., vol.39, no.2, pp.504-510, Mar./Apr. 2003.

[3] Chub, A.; Vinnikov, D.; Blaabjerg, F.; and Peng, F.Z., "A Review of Galvanically Isolated Impedance-Source DC-DC Converters," IEEE Transactions on Power Electronics, to be published. DOI: 10.1109/TPEL.2015.2453128.

[4] Shults, T.; Husev, O.; and Zakis, J., "Overview of impedance source networks for voltage source inverters," Proc. 2015 16th International Conference of Young Specialists on Micro/Nanotechnologies and Electron Devices (EDM), pp.514-520, 2015.

[5] Yushan Liu; Abu-Rub, H.; and Baoming Ge, "Z-Source/Quasi-Z-Source Inverters: Derived Networks, Modulations, Controls, and Emerging Applications to Photovoltaic Conversion," IEEE Ind. Electron. Mag., vol.8, no.4, pp.32-44, Dec. 2014.

[6] Anderson, J.; and Peng, F.Z., "Four quasi-Z-Source inverters," Proc. 2008 IEEE Power Electronics Specialists Conference (PESC'2008), pp.2743-2749, 15-19 June 2008.

[7] Mishra, S.; Adda, R.; and Joshi, A., "Inverse Watkins-Johnson Topology-Based Inverter," IEEE Trans. on Power Electron., vol.27, no.3, pp.1066-1070, Mar. 2012.

[8] Nag, S.S.; and Mishra, S., "Current-Fed Switched Inverter," IEEE Trans. on Ind. Electron., vol.61, no.9, pp.4680-4690, Sept. 2014.

[9] Nguyen, M.-K.; Le, T.-V.; Park, S.-J.; and Lim, Y.C., "A Class of Quasi-Switched Boost Inverters," IEEE Trans. on Ind. Electron., vol.62, no.3, pp.1526-1536, March 2015.

[10] Nguyen, M.-K.; Lim, Y.-C.; and Park, S.-J., "A Comparison between Single-Phase Quasi-Z-Source and Quasi-Switched-Boost Inverters," IEEE Trans. on Ind. Electron., to be published. DOI: 10.1109/TIE.2015.2424201.

[11] Vinnikov, D.; Roasto, I.; Strzelecki, R.; and Adamowicz, M., "Step-Up DC/DC Converters With Cascaded Quasi-Z-Source Network," IEEE Trans. on Ind. Electron., vol.59, no.10, pp.3727-3736, Oct. 2012.

[12] Siwakoti, Y.P.; Blaabjerg, F.; and Loh, P.C., "New Magnetically Coupled Impedance (Z-) Source Networks," IEEE Trans. on Power Electron., to be published. DOI: 10.1109/TPEL.2015.2459233.

[13] Loh, P.C.; and Blaabjerg, F., "Magnetically Coupled Impedance-Source Inverters," IEEE Trans. on Ind. Appl., vol.49, no.5, pp.2177-2187, Sept.Oct. 2013.

[14] Qin Lei; Peng, F.Z.; and Miaosen Shen, "Switched-coupled-inductor inverter," Proc. 2013 IEEE Energy Conversion Congress and Exposition (ECCE), pp.5280-5287, 15-19 Sept. 2013.

[15] Ahmed, F.; Cha, H.; Kim, S.; and Kim, H., "Switched-Coupled-Inductor Quasi-Z-Source Inverter," IEEE Trans. on Power Electron., to be published. DOI: 10.1109/TPEL.2015.2414971

[16] Berkovich, Y.; and Axelrod, B., "Switched-coupled inductor cell for DC-DC converters with very large conversion ratio," IET Power Electron., vol.4, no.3, pp.309-315, Mar. 2011.

[17] Siwakoti, Y.P.; Loh, P.C.; Blaabjerg, F.; and Town, G.E., "Effects of Leakage Inductances on Magnetically Coupled Y-Source Network," IEEE Trans. on Power Electron.,vol.29,no.11,pp.5662-5666, Nov. 2014.

[18] Axelrod, B.; Berkovich, Y.; and Ioinovici, A., "Switched-Capacitor/ Switched-Inductor Structures for Getting Transformerless Hybrid DCDC PWM Converters," IEEE Trans. on Circuits and Systems I: Regular Papers, vol.55, no.2, pp.687-696, Mar. 2008.

[19] Takiguchi, T.; and Koizumi, H., "Quasi-Z-source dc-dc converter with voltage-lift technique," Proc. 39th Annual Conference of the IEEE Industrial Electronics Society (IECON 2013), pp.1191-1196, 10-13 Nov. 2013.

[20] Ding Li; Loh, P.C.; Zhu, M.; Feng Gao; and Blaabjerg, F., "Generalized Multicell Switched-Inductor and Switched-Capacitor Z-Source Inverters," IEEE Trans. on Power Electron., vol.28, no.2, pp.837-848, Feb. 2013.

[21] Itozakura, H.; and Koizumi, H., "Embedded Z-source inverter with switched inductor," Proc. 37th Annual Conference on IEEE Industrial Electronics Society (IECON'2011), pp.1342-1347, 7-10 Nov. 2011.

[22] Nguyen, M.-K.; Lim, Y.C.; Chang, Y.H.; and Moon, C.-J., "Embedded Switched-Inductor Z-Source Inverters," Journal of Power Electronics, vol.13, no.1, pp.9-19, Jan. 2013.
[23] Miao Zhu; Kun Yu; Fang Lin Luo, "Switched Inductor Z-Source Inverter," IEEE Trans. on Power Electron., vol.25, no.8, pp.2150-2158, Aug. 2010

[24] Deng, K.; Zheng, J.; and Mei, J., "Novel Switched-Inductor Quasi-Zsource Inverter," Journal of Power Electronics, vol.14, no.1, pp.11-21, Jan. 2014

[25] Minh-Khai Nguyen; Young-cheol Lim; Geum-Bae Cho, "SwitchedInductor Quasi-Z-Source Inverter," IEEE Trans. on Power Electron., vol.26, no.11, pp.3183-3191, Nov. 2011.

[26] Nguyen, M.-K.; Lim, Y.-C.; Choi, J.-H., "Two switched-inductor quasiZ-source inverters," IET Power Electronics, vol.5, no.7, pp.1017-1025, Aug. 2012.

[27] Chub, A.; Husev, O.; Zakis, J.; Rabkowski, J., "Switched-Capacitor Current-Fed Quasi-Z-Source Inverter," Proc. 14th Biennial Baltic Electronics Conference (BEC'2014), pp.229-232, 6-8 Oct. 2014.

[28] Ho, A.-V.; Chun, T.-W., and Kim, H.-G., "Development of Multi-Cell Active Switched-Capacitor and Switched-Inductor Z-Source Inverter Topologies," Journal of Power Electronics, vol.14, no.5, pp.834-841, Sept. 2014.

[29] Ho, A.V.; Chun, T.W., and Kim, H.G., "Extended Boost ActiveSwitched-Capacitor/Switched-Inductor Quasi-Z-Source Inverters," IEEE Trans. on Power Electron., vol.30, no.10, pp.5681-5690, Oct. 2015.

[30] Gajanayake, C.J.; Fang Lin Luo; Hoay Beng Gooi; Ping Lam So; Lip Kian Siow, "Extended-Boost Z -Source Inverters," IEEE Trans. on Power Electron., vol.25, no.10, pp.2642-2652, Oct. 2010.

[31] Shen, M.; Peng, F.Z., "Operation Modes and Characteristics of the ZSource Inverter With Small Inductance or Low Power Factor," IEEE Trans. on Ind. Electron., vol.55, no.1, pp.89-96, Jan. 2008.

Andrii Chub received the B.Sc. degree in Electronics and M.Sc. degree in Electronic Systems from Chernihiv State Technological University, Chernihiv, Ukraine, in 2008 and 2009, respectively. He is currently pursuing the Ph.D. degree in the Power Electronics Research Group, Tallinn University of Technology, where he is employed as a Junior Researcher at the Department of Electrical Engineering. He has co-authored more than 25 papers and one book chapter on power electronics and applications.

His research interests include dc-dc converters, dc-ac inverters, impedance source electric energy conversion technology, implementation of the new wide bandgap semiconductors in power converters, and control of renewable energy conversion systems.

E-mail: andrii.chub@ieee.org

Liisa Liivik received Dipl. Eng, M.Sc. and Ph.D. degrees in Electrical Engineering from Tallinn University of Technology, Tallinn, Estonia, in 1998, 2000 , and 2015, respectively. She is presently a Researcher in the Power Electronics Research Group of the Department of Electrical Engineering, Tallinn University of Technology. Her research interests include design, simulation and experimental validation of switch mode converters for distributed power generation systems. She has published over 20 research papers and one textbook

Janis Zakis (M'10 - SM'14) received B. Sc., M. Sc. and Dr. Sc. ing. degrees in Electrical Engineering from Riga Technical University, Riga, Latvia, in 2002, 2004 and 2008, respectively. He is currently a Senior Researcher with the Institute of Industrial Electronics and Electrical Engineering, Riga Technical University. He has over 50 publications in journals and conference proceedings. His current research interests include design and simulation of novel multilevel converter topologies, applied design of power converters and energy storage systems.

Dmitri Vinnikov received the Dipl. Eng., M.Sc., and Dr.Sc.techn. degrees in Electrical Engineering from Tallinn University of Technology, Tallinn, Estonia, in 1999, 2001, and 2005, respectively. He is currently Head of the Power Electronics Research Group at the Department of Electrical Engineering, Tallinn University of Technology and Scientific Consultant at the Institute of Industrial Electronics and Electrical Engineering, Riga Technical University.

He has authored more than 150 published papers on power converter design and development and is the holder of several patents and utility models in this area. His research interests include switch-mode power converters, modeling and simulation of power systems, applied design of power converters and control systems, and application and development of energy storage systems. 